\title{
Rain Measurement with SIR-C/X-SAR
}

\author{
R. K. Moore, A. Mogili, Y. Fang, B. Beh, A. Ahamad \\ University of Kansas, Radar Systems and Remote Sensing Laboratory \\ 2291 Irving Hill Road, Lawrence KS 66045-2969 USA \\ TEL: 913/864-4736 , FAX: 913/864-7789 , E-mail: rmoore@eecs.ukans.edu
}

Abstract-Rain measurements by ground-based radar are unavailable in many parts of the world, especially the oceans. Because many SARs will be flying in space, we (a group headed by Dr. F. Li of JPL) performed an experiment using the SIR-C/X-SAR radars to test the ability of spaceborne SARs to measure rain rates. SAR resolution in rain is degraded by Doppler shifts due to turbulent motion of the rain (Atlas and Moore, 1987). The wide vertical beam required to achieve SAR ground coverage means that one must accept a path-integrated estimate of the rain rate. We used two approaches to rain measurement using the SIR-C/X-SAR radars pointed well off vertical. Over the western Pacific Ocean, we used the strength of the rain echo to estimate rain rate using an appropriate $Z-R$ relation, as do ground-based radars. To separate rain echo from surface echo, one must estimate the surface contribution to the signal. Over the Amazon rain forest where the shadows are obvious we used the reduction of signal in the shadow due to attenuation through a rain storm.

\section{THE EXPERIMENT}

SIR-C was a multi-polarized SAR with frequencies in $\mathrm{L}$ band and $C$ band while the X-band X-SAR used only vertical (VV) polarization. The SRL-1 mission was in April 1994, and the SRL-2 mission in September-October 1994. We obtained storm images from both in both the southwest Pacific and in Brazil.

We could only turn the radars on a few times, with requests needed about 20 hours in advance for the southwest Pacific passes. The Brazil passes were scheduled for other purposes. For rain forecasts, the JPL team used cloud IR images from the GMS satellite and the Kansas team obtained forecasts of precipitation from the Australian Bureau of Meteorology at 6hour intervals. Forecast maps from the Singapore Meteorological Service were also used.

\section{THE PACIFIC OCEAN EXPERIMENT}

Methodology

Users of ground-based weather radars get rain rates by inverting the radar equation for volume scatter. The volume scattering coefficient relates to the quantity $Z$, the mean sum of (drop sizes) $6 / \mathrm{m} 3$ in $\mathrm{mm} 6 / \mathrm{m} 3$ by

$$
\eta=10^{-10} \frac{\pi^{6}}{\lambda^{4}}\left|K_{w}\right|^{2} Z
$$

where $\left|K_{w}\right|^{2}$ is a function of the refractive index of water, temperature and wavelength, and $\eta$ is the volume-scattering coefficient. For practical purposes, at the wavelengths and temperatures here, we may consider it to be 0.93 .

Many relations have been reported between $Z$ and rain rate $R[1,2]$. We elected to use two relations: $Z=300 \mathrm{R} 1.5$ and $Z=170 \mathrm{R} 1.47$ from [3], based on drop-size distribution for convective cells measured in the area of our experiment during TOGA-COARE.

To determine the scattering volume we had to assume a height for the rain column and the rms turbulent velocity needed to get the along-track resolution. The thickness of the cell is the range resolution. The width of the shell must be determined from the assumed rms turbulent velocity. Using the analysis of [4], this width (the azimuth resolution) is

$$
r_{a}=\frac{2 u_{t} R}{u}
$$

where $u_{t}$ is the rms turbulent velocity assumed for the rain drops and $u$ is the spacecraft speed. Our analysis applies only when the entire range shell is within the storm. We ignored other cases in our calculations.

This result can only be used when is small enough to be ignored. If we must consider the attenuation to the bottom of the storm, one must correct the volume $V$ of a range shell for the differential attenuation suffered by different parts of the shell. Of the numerous values of extinction coefficient $\mathrm{K}_{\mathrm{er}}$ in the literature, we used [5]

$\mathrm{K}_{\mathrm{er}}=0.002 \mathrm{R} \mathrm{dB} / \mathrm{km}$ or $0.00023 \mathrm{R} \mathrm{Np} / \mathrm{km}$ at $\mathrm{C}$ band $(\lambda=5.7 \mathrm{~cm})$

$\mathrm{K}_{\mathrm{er}}=0.008 \mathrm{R} 1.1 \mathrm{~dB} / \mathrm{km}$ or $0.00092 \mathrm{R}^{1.1} \mathrm{~Np} / \mathrm{km}$ at $\dot{\mathrm{X}}$ band $(\lambda=3.2 \mathrm{~cm})$.

These expressions require the rain rate, which is initially unknown, so an iterative procedure is necessary.

Since both rain echo and surface echo are random signals, we may get the rain echo by subtracting an estimate of the surface echo. We could use the surface echo from rain-free regions nearby, but this ignores both the effect of higher winds in a convective cell and of raindrops striking the water $[5,6]$. We estimated the wind in the convective cells to be 15 $\mathrm{m} / \mathrm{s}$ (may be high), and obtained the scattering coefficient from the CMOD4 model [7] for C band and the SASS model [8] for $\mathrm{X}$ band, assuming cross-wind conditions.

\section{Observations}

Pass 13.4 of the Shuttle Radar Lab (SRL) was near Ontong Java Atoll in the South Pacific with an angle of incidence of $48^{\circ}$. The center of the images is at $6^{\circ} \mathrm{S} 159^{\circ} \mathrm{E}$. Fig. 1 

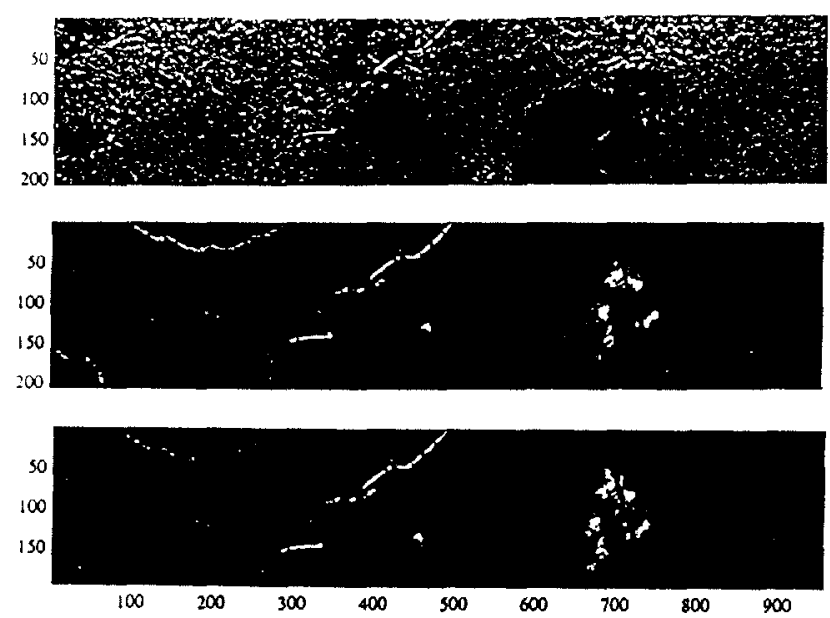

Fig. 1 L-, C-, and X-band images for pass 13.4 at $6^{\circ} \mathrm{S} 159^{\circ}$ E. The bright curved lines present in all images are from Ontong Java Atoll. Rain cells are apparent to the east of the atoll in the $\mathrm{C}$ - and X-band images.

shows 100-km-long L-, C-, and X-band images of the area. The outline of a part of Ontong Java Atoll shows in all images and we see rain cells in the $C$-band and $X$-band images. We analyzed the strong storm cell that shows roughly between 710 and 790 on the horizontal axis. Dark spots on the L-band image occur near the brightest regions on the $\mathrm{C}$ - and $\mathrm{X}$-band images, suggestg echo rain drops hitting the surface as reported by Atlas [9].

We assumed the storm height to be $4.5 \mathrm{~km}$, and a reasonable value of $3.5 \mathrm{~m} / \mathrm{s}$ as the rms turbulent velocity in the storm. Clearly the assumptions used affect the rain estimates.

We computed rain rates for three storms during the first mission and one during the second mission, but we report here results of only one set of measurements. Each storm was a relatively small cell, obviously convective from its size.

Tables 1 and 2 show the measured apparent rain signal in $\mathrm{dBZ}$, ordered by signal strength in different parts of the storm echo. The corrected values shown $\left(\mathrm{dBZ} 1\right.$ for $Z=300 \mathrm{R}^{1.5}$ and $\mathrm{dBZ2}$ for $Z=170 \mathrm{R}^{1.44}$ ) come from removing the surface echo using attenuation of the surface echo for each of the $Z-R$ relations. The rain rates $(R 1, R 2)$ are based on the two $Z-R$ relations. Finally, we show a modified $\mathrm{dBZ}$ and a corrected rain rate $(R / C, R 2 C)$ based on the correction for attenuation of part of the rain echo.

The rain rate using the expression of [3] is nearly double that for $Z=300 R^{1.5}$. We believe that the higher rate is likely to be a better estimate because it is based on convective storms in the same part of the world. Unfortunately, no surface measurements are available to verify this. Auki, Malaita, Solomon Islands weather station reported thunderstorms in the vicinity.

The $\mathrm{C}$-band $\mathrm{dBZ}$ values often are larger than those at $\mathrm{X}$ band without the attenuation correction. However, the attenuation-correction seems to overcorrect the X-band values.
This could be due to overestimating the attenuation rate using (3), to non-uniform density of the rain, or to some other problem.

\begin{tabular}{|r|r|r|r|r|r|l|l|l|}
\hline $\mathrm{dBZ}$ & $\mathrm{dBZ1}$ & $\begin{array}{l}\mathrm{Mod} \\
\mathrm{dBZ} 1\end{array}$ & $\begin{array}{l}\mathrm{R} 1 \\
\mathrm{~mm} / \mathrm{hr}\end{array}$ & $\begin{array}{l}\mathrm{RIC} \\
\mathrm{mm} / \mathrm{hr}\end{array}$ & $\mathrm{dbZ2}$ & $\begin{array}{l}\mathrm{Mod} \\
\mathrm{dBZ2}\end{array}$ & $\begin{array}{l}\mathrm{R} 2 \\
\mathrm{~mm} / \mathrm{hr}\end{array}$ & $\begin{array}{l}\mathrm{R} 2 \mathrm{C} \\
\mathrm{mm} / \mathrm{hr}\end{array}$ \\
\hline 46.8 & 45.5 & 45.7 & 24.2 & 24.7 & 45.6 & 45.9 & 41.6 & 43.2 \\
\hline 46.9 & 45.7 & 45.9 & 24.8 & 25.5 & 45.8 & 46.1 & 42.8 & 44.7 \\
\hline 47.4 & 46.3 & 46.5 & 27 & 28.0 & 46.3 & 46.6 & 46.7 & 48.6 \\
\hline 47.7 & 46.7 & 46.9 & 29.1 & 29.8 & 46.8 & 47.1 & 50.4 & 52.9 \\
\hline 48.1 & 47.2 & 47.4 & 31.2 & 32.2 & 47.3 & 47.6 & 54.1 & 57.5 \\
\hline 48.3 & 47.5 & 47.7 & 32.6 & 33.8 & 47.5 & 47.9 & 56.6 & 59.5 \\
\hline
\end{tabular}

Table $1 \mathrm{C}$-band rain reflectivity and rain rates, SRL-1. Location $5^{\circ} \mathrm{S} 159^{\circ} \mathrm{E}$.

$\mathrm{dBZ}$ is rain reflectivity with no corrections. $\mathrm{dBZ1}$ is value corrected for surface echo, assuming attenuation for rain rate $R 1$ obtained $w / Z=300 R^{1.5}$. Mod $d B Z 1$ is value of $d B Z 1$ corrected using effect of attenuation on rain echo. RIC is $R I$ value corrected using effect of attenuation on rain echo. $\mathrm{dBZ2}$ is value corrected for surface echo, assuming attenuation for rain rate $R 2$ obtained with $Z=170 R^{144}$. Mod $d B Z 2$ is value of $d B Z 2$ corrected using effect of attenuation on rain echo. $R 2 C$ is $R 2$ value corrected using effect of attenuation on rain echo.

\begin{tabular}{|r|r|r|r|r|r|r|r|r|}
\hline $\mathrm{dBZ}$ & $\mathrm{dBZl}$ & $\begin{array}{l}\mathrm{Mod} \\
\mathrm{dBZl}\end{array}$ & $\begin{array}{l}\mathrm{Rl} \\
\mathrm{mm} / \mathrm{hr}\end{array}$ & $\mathrm{RlC}$ & $\mathrm{dbZ2}$ & $\mathrm{Mod}$ \\
$\mathrm{mm} / \mathrm{hr}$ & $\mathrm{R} 2$ & $\mathrm{R} 2 \mathrm{C}$ \\
$\mathrm{dBZ2}$ & $\mathrm{mm} / \mathrm{hr}$ & $\mathrm{mm} / \mathrm{hr}$ \\
\hline 44.7 & 43.8 & 44.4 & 18.5 & 20.4 & 43.9 & 45.0 & 31.8 & 37.6 \\
\hline 46.3 & 45.7 & 46.6 & 25.1 & 28.3 & 46 & 47.5 & 43.4 & 56.3 \\
\hline 47.4 & 47 & 48.0 & 30.2 & 35.6 & 47.1 & 48.9 & 52.5 & 70.7 \\
\hline 48.1 & 47.7 & 48.9 & 33.9 & 40.4 & 47.8 & 49.9 & 59.1 & 82.1 \\
\hline 48.3 & 48 & 49.2 & 35.3 & 42.7 & 48.1 & 50.3 & 61.7 & 87.3 \\
\hline 48.7 & 48.7 & 50.1 & 39.5 & 48.6 & 48.8 & 51.2 & 69.3 & 101.9 \\
\hline
\end{tabular}

Table $2 \mathrm{X}$-band rain reflectivity and rain rates, SRL-1. Location $5^{\circ} \mathrm{S} 159^{\circ} \mathrm{E}$. Legend same as Table 1.

\section{THE AMAZON RAIN FOREST EXPERIMENT}

\section{Methodology}

Meneghini $[10,11]$ proposed a surface-reference technique (SRT) to estimate the path-averaged rain rate from the direct measurement of total rain attenuation, using the difference between signals from the surface in rain and outside the rain area. We used this method to estimate rain rate from rain shadows on images of the Amazon rain forest. Surface echoes in the shadow are given by $\sigma^{0} \mathrm{~A}$, where $\mathrm{A}$ is the attenuation factor. If we know the path length through the rain volume between radar and surface target, we can get $K_{e r}$, the attenuation coefficient in $\mathrm{dB} / \mathrm{km}$. Inverting the usual $K_{e r}-R$ law gives the average rain rate.

This technique does not use any rain-echo information. The surface-reference technique depends on comparing echoes in the shadow that are reduced by the integrated rain attenuation with echoes outside the shadow region. We used a simple 
model to characterize the radar signal returns for the rain cell. Assumptions for the model are: 1) the rain is in a rectangular cylinder with height of $h$ and width of $w ; 2)$ the $\sigma^{0}$ of the surface clutter is assumed to be constant; 3) the volume scattering from the rain is much smaller than the surface echo.

The model has two cases: 1) rain cell is long enough for a complete ray from top to ground within the rain, a low but widespread rain cell; and 2) a higher but smaller rain cell, in which the ray from the top of the rain passes out the back of the cell and therefore has less attenuation.

Fig. 2 shows the simulated range-profile signal for the model. The profile for the ground returns contains three segments. In the first segment, the surface return decreases with range with a slope proportional to the attenuation factor. In the second segment the attenuated path length remains constant, as does the ground return. In the third segment the return increases with the increasing range until the radar beam misses the rain.
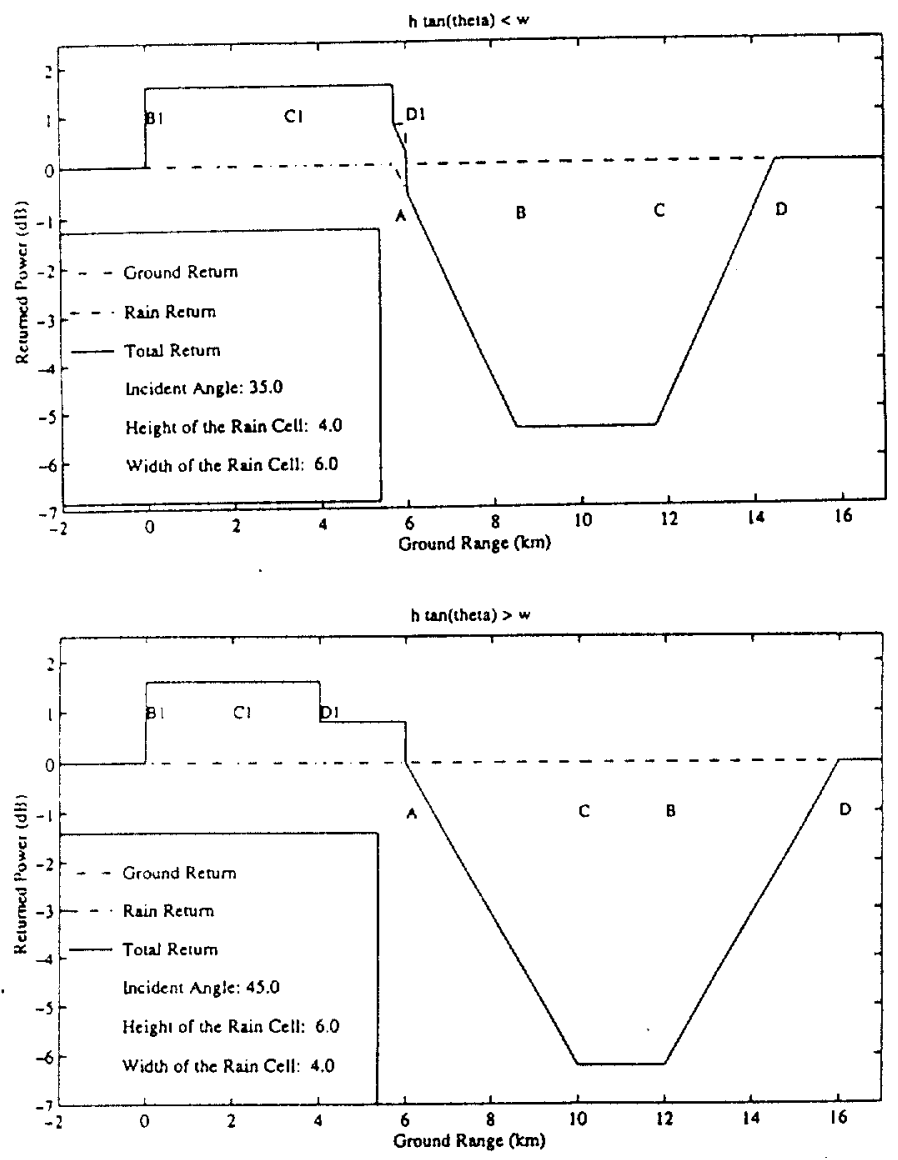

Fig. 2 Profiles of expected signals in presence of rain cell. Note that for case 1, the path length within the rain cell $C^{\prime}$ ' is equal to $B^{\prime}$ ' whereas for case $2, C^{\prime}=$ $B B^{\prime}-B C$. This is an uncertainty in path length determination.

The Doppler frequency shift from rain drop motion can shift the rain echo away from the shadow by as much as $1 \mathrm{~km}$.
Note the shift for the rain cell shown in the upper right corner of Fig. 3. The rain shadows usually appear to have a fan shape. This may be because of the irregular shape of the rain cell, but the very long synthetic aperture of a spaceborne SAR can also contribute when the signal from only one end of the synthetic aperture passes through the rain.

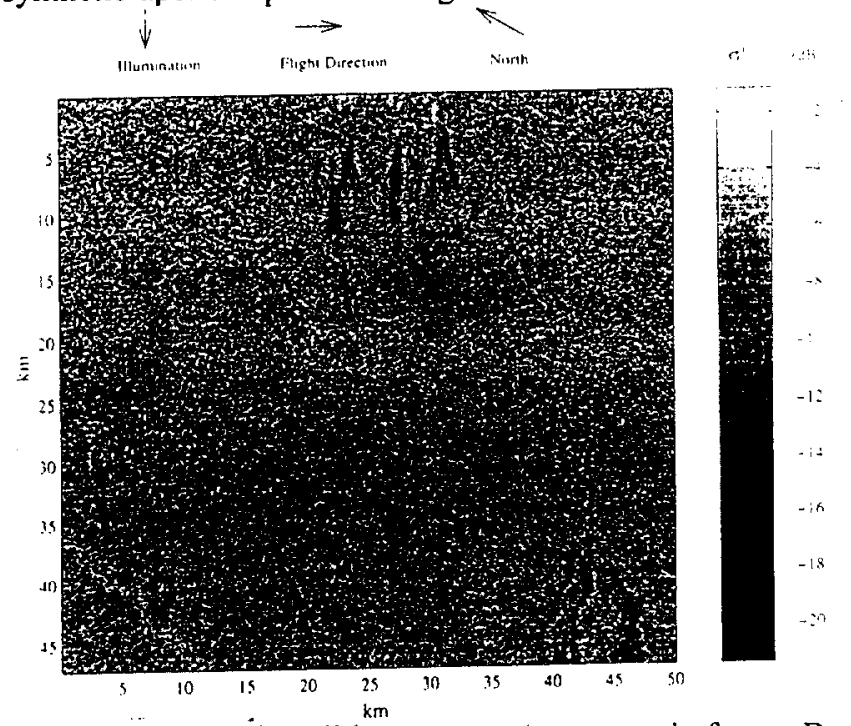

Fig. 3 X-SAR rain cell image over Amazon rain forest. Data take ID 103.60

Since the image pixels for the rain cell and its shadow are not necessarily well aligned, we cannot get the correct range profile of the signal return for the rain by plotting the signal returns on the same range line. To determine the right $\sigma^{0}$ value at a certain range, we pick portions with the strongest return along the track when the range is within the rain, while we pick portions with the weakest returns beyond the rain (inside the rain shadow).

\section{Observation}

Here we used the image from pass 103.60 taken by SIR$\mathrm{C} / \mathrm{X}-\mathrm{SAR}$ at $43^{\circ}$ incidence over the Amazon rain forest region during SRL-2. The overall results are stated in Table 3. The surface-reference technique (attenuation method) gives excellent results compared with the backscatter method used over the ocean. Both X-and $\mathrm{C}$-band data give reasonable and similar results. The rain rates obtained from the $\mathrm{C}$-Band image are less than from the X-Band image; but with the uncertainties in the $\mathrm{K}_{\mathrm{er}}$ relations, these differences are not large.

\section{CONCLUSIONS}

Spaceborne SAR could provide information about rain rates in suitable areas of the world, but the errors in the rain rates retrieved can be large because of the many assumptions needed. However, the ground-mapping SARs are far from optimum for the purpose. A special-purpose SAR for rain [4] 
would not have these limitations, but would be expensive for this application.

Our two approaches used Z-R relations for ocean and measurement of attenuation through rain cells for land. We presented examples of use of both methods for the SIR-C/XSAR radars flown on the Shuttle in 1994. Retrieved rain rates over the Southwest Pacific were more variable because they required so many assumptions. Rain rates retrieved over the Amazon rain forest were less variable because we needed to make fewer assumptions.

\begin{tabular}{|l|c|r|c|c|c|}
\hline $\begin{array}{c}\text { Frequency } \\
\text { Band }\end{array}$ & $\mathrm{a}$ & $\mathrm{b}$ & $\begin{array}{c}\text { Attenuation } \\
\text { (two way in } \\
\mathrm{dB})\end{array}$ & $\begin{array}{c}\text { Path Length } \\
\text { within } \\
\text { raincell }(\mathrm{km})\end{array}$ & $\begin{array}{c}\text { rain rate } \\
(\mathrm{mm} / \mathrm{hr})\end{array}$ \\
\hline $\mathrm{X}$ & 0.008 & 1.1 & 5.4 & 6.5 & 83 cell 1 \\
\hline $\mathrm{C}$ & 0.002 & 1 & 2.0 & 6.5 & 77 cell 1 \\
\hline $\mathrm{X}$ & 0.008 & 1.1 & 5.5 & 6.1 & 89 cell 2 \\
\hline $\mathrm{C}$ & 0.002 & 1 & 2.0 & 6.1 & 82 cell 2 \\
\hline $\mathrm{X}$ & 0.008 & 1.1 & 7 & 5.5 & 128 cell 3 \\
\hline $\mathrm{C}$ & 0.002 & 1 & 2.4 & 5.5 & 109 cell 3 \\
\hline
\end{tabular}

Table 3 Rain rates in the Amazon rain forest.

We estimated rain rates over the ocean in the range of 20 to $140 \mathrm{~mm} / \mathrm{hr}$ using a Z-R relation based on drop-size distributions measured in convective storms in the same general area. Rain cells over the Amazon basin show bright echoes at $\mathrm{X}$ band and strong shadows at both $\mathrm{X}$ band and $\mathrm{C}$ band. Rates of 77 to $109 \mathrm{~mm} / \mathrm{hr}$ were estimated using the attenuation method. These seem reasonable for tropical convective storms. We believe this first attempt at using off-nadir SAR rain echoes and shadows to determine the rain shows that the methods used have potential to expand our climatology of rain by use of spaceborne SARs.

\section{ACKNOWLEDGMENTS}

This work was supported by NASA through JPL contract 958522. The work was done cooperatively with the group at JPL, including Fuk Li, Steve Durden, and Ziad Haddad.

\section{REFERENCES}

[1] R. Wexler and D. Atlas,"Radar reflectivity and attenuation of rain,"J.Appl.Meteor., vol.2, pp. 276-280, 1963.

[2] L. J. Battan, Radar Observation of the Atmosphere, Chicago, Univ. Chicago Press, 1973, 324 pp.

[3] A. Tokay, D. A. Short, and O. W. Thiele, "Convective vs. stratiform rain over Kapingamarangi Atoll during TOGACOARE: Evidence from raindrop spectra," J. App. Meteor., in press.

[4] D. Atlas and R. K. Moore, "The measurement of precipitation with synthetic aperture radar," J. Atmos. \& Oceanic Tech. vol. 4, pp. 368-376, 1987.

[5] R. K. Moore, Y. S. Yu, A. K. Fung, D. Kaneko, G. J. Dome, and R. E. Werp, "Preliminary study of rain effects on radar scattering from water surfaces," IEEE Comm. in J. Oceanic Eng., vol. OE-4, pp. 31-32, 1979.

[6] L. F. Blivens and G. Norcross, "Effects of rainfall on scatterometer derived wind fields," Digest IGARSS'88, vol. 1, pp. 565.566, 1988.

[7] W. H. Gemmill, P. Woiceshyn, C. A. Peters, and V. M. Gerald, "A Preliminary Evaluation of Scatterometer Wind Transfer Functions for ERS-1 Data," NMC/OPC Tech. Note. 20746, Camp Springs MD, Ocean Product Center, 1994.

[8] L. C. Schroeder, et al., "The relationship between wind vector and normalized radar cross-section used to derive Seasat-A satellite scatterometer winds," J. Geophys. Res., vol. 87, pp. 3318-3386, 1982.

[9] D. Atlas, "Footprints of storms on the sea: A view from spaceborne synthetic aperture radar," J. Geophys. Res., vol. 99, pp. 7961-7969, 1994.

[10] R. Meneghini and D. Atlas, "Determination of rain rate from a spaceborne radar using measurement of total attenuation," IEEE Trans. on Geosci. \& Rem. Sens., vol. 21, pp. 34-43, 1983.

[11] R. Meneghini, J. A. Jones, and L. H. Gesell, "Analysis of a dualwavelength surface reference radar technique," IEEE Trans. Geosc. \& Rem. Sens., vol. 25, pp. 456-471, 1987. 